\title{
The Effect of Direct and Indirect Corrective Feedback on Students' Writing Quality
}

\author{
Siti Mafulah ${ }^{1 *}$ and Yazid Basthomi ${ }^{2}$ \\ ${ }^{1}$ Universitas PGRI Kanjuruhan Malang and Student of ELT Postgraduate program, Universitas Negeri Malang \\ ${ }^{2}$ Universitas Negeri Malang \\ *Corresponding author. Email: siti_mafulah@unikama.ac.id
}

\begin{abstract}
Giving feedback both direct and indirect is believed to help students write better. This paper aims to investigate whether there is an effect of direct corrective feedback on students' writing quality. There were 26 students as participants. Each student was exposed to two different types of feedback, they are direct and indirect feedback. After receiving each type of feedback, the students' writings were analyzed. The individual score of the students were compared to know the effect of the given feedback. The stastical analysis showed that the students' writings were better when they recieved direct feedback than the indirect one. Direct feedback helped students in revising their draft more accurate than when they received indirect feedback. It is suggested that the teachers apply direct corrective feedback to help students perform better in writings. Furthermore, future reasearchers intending to conduct similar study are recommended to use larger size of participants in order to confirm the effectiveness of different feedback types. A particular aspect of grammatical errors can be investigated further to know the effectiveness of each corrective feedback type.
\end{abstract}

\section{Keywords: direct feedback, indirect feedback, writing, writing quality}

\section{INTRODUCTION}

Teacher feedback is effective for students' writing quality when it is given to the students in the process of writing. Students will recognize and identify the error that they have made through teacher feedback so that they can write better. Direct feedback, indirect feedback, metalinguistic feedback, focused (selective) feedback, unfocused (comprehensive) feedback, electronic feedback, and reformulation are various of teacher feedback that can be an alternative way to be given to the students [1]. Among those types of written corrective feedback, the most widely studied by researchers are direct and indirect feedback [2].

Direct and indirect feedback on writing have been studied by some scholars. for example, study concerning written corrective feedback that focus on accuracy in grammar aspect [3]. Study of feedback that focus on verb tense accuracy [4], on lexical error [5] and on article [6]. Some research results showed the same effect on the students writing after receiving direct and indirect feedback [7], [8]. It means that both direct and indirect feedback given by teacher have great effect to the students in resulting better writing. Furthermore, students become better self-editing after receiving feedback from the teacher and after taking grammar class with treatment, intensive feedback from the teacher [9].
There are some different findings related to the effectiveness of the implementation among feedback types on students' writings. It enables students to see their errors and enables them to do self-correction [6], [5]. Bitchener and Knoch [6] studied the students' use of article after 10 weeks receiving direct and indirect feedback on their writing process. The finding shows that the students who receive direct added by some explanation of metalinguistic part got better writing that student who receive other feedback. furthermore, the students who receive indirect feedback, they cannot make better correction of their errors in the first stage of treatment. Similar finding show that direct corrective feedback was suited for grammatical errors compared to indirect feedback [5]. In addition, students can write properly when the teacher applies corrective feedback and focus on a single linguistics feature [10]. It means that when teacher gives feedback and focus on one aspect of writings, students understand their mistakes and revise their writing well.

However, different findings in linguistics aspect were found. Indirect feedback is more beneficial for students to solve their problems or errors compares to direct feedback[11], [12]. Furthermore, they argue that direct feedback is only suitable for students who have limited linguistic knowledge or lower-level students. In addition, Frear and Chiu [11] experimenting 
focused and unfocused indirect written corrective feedback as the experimental group and a control group. The finding of the study shows that in short term effect, students who in a control group has lower achievement that those who received feedback as treatment. Moreover, the students show better writing result in the delayed post-test when they revise their writing after receiving feedback from teacher. From this study can be concluded that giving feedback both direct and indirect feedback may give significance effect to the students' writing achievement. Another research study was conducted by Muthi'm and Latief [12]. They experimented three types of corrective feedback; feedback with providing sample and comment, feedback through giving code, and feedback with no code correction. The finding shows the effectiveness of the three types of feedback, but each group has different enhancement of the writing component. The group with coded-corrective feedback made progress in the following components of writing: first they show their progress in content or ideas of writing, organization, vocabulary, and mechanics. Non-coded corrective feedback made progress in content, organization, language use, and mechanics. Although it has different improvement in the component of writing, indirect feedback seems to be better than direct feedback. The difference of the findings needs more empirical studies to support which one is suitable for the teacher to help students revising their writing. Therefore, the implementation of direct and indirect feedback should be studied deeper.

Further investigation was on the implementation of different corrective feedback in specific aspect like students' grammatical awareness [13]. The result shows that target structures accuracy was reached by the students through revising their writing after receiving feedback both direct and indirect. Moreover, the improvement of the students' writing on past perfect in new writing (delayed post-test) has significantly increased if it is compared with the first writing. Besides, the different finding found on the study on feedback focusing on subject verb agreement [13]. They claim that students fixed their subject verb agreement better when they got indirect feedback than when they got direct feedback. The success of corrective feedback in helping students, improving their writings, and the different result of the studies raises curiosity whether both types of feedback have the same effect on students in different setting. So that this study should be conducted.

Previous studies have examined the effect of feedback types both direct and indirect feedback. The previous studies mostly focused on specific aspect of writing component so that further research regarding other aspects of writing such as content, organization, vocabulary, and mechanic should be conducted [14]. Therefore, the aim of this study is to compare whether there is significant difference between direct and indirect corrective feedback on writing quality. The quality of students writing in this study involves those aspects of writing. Based on the aim mentioned, the research question is formulated as follows:

Is there any difference between direct and indirect corrective feedback on students' writings quality?

\section{METHOD}

The participant of this study was twenty-six students of English Education department. They were all third-year students at Universitas PGRI Kanjuruhan Malang, Indonesia. The participants were students who joined Essay Writing Class. The study was conducted in two weeks, each week was consisted of two meetings. Every student had to write twice with different topic and given two different types of feedback. To counterbalance the effect of giving different feedback, the students were divided into 2 groups, each group consisted of 13 students. First meeting, they were asked to write composition 1 with topic Indonesian Forest Fires in the classroom. Group one got direct feedback and group two got indirect feedback. In the second meeting, the students received their first composition then they had to revise their writing in the classroom before submitting the final draft. The final revisions were analyzed by the teacher. Third meeting, they wrote composition 2 with topic several artists were pointed to be parliament member. They received different order of feedback, in this meeting group 1 received indirect feedback while group 2 received direct feedback. The last meeting, the students got their second composition back and wrote the final revision based on the feedback given. The revision was done in the classroom. Detail information of the activities done in this study can be seen in table 2 .

Students' writings were assessed using a scoring rubric. The components were assessed were content, organization, language use including grammatical aspect, vocabulary, and mechanics. Each component of writing has different weights: 5 for content, 5 for organization, 7 for language use, 2 for vocabulary and 1 for mechanics (see table 1)

Table 1. Scoring Rubric for Students' Writing

\begin{tabular}{|l|l|c|c|}
\hline No & Component & Weighting & Maximum Score \\
\hline 1 & Content & 5 & 25 \\
\hline 2 & Organization & 5 & 25 \\
\hline 3 & Language Use & 7 & 35 \\
\hline 4 & Vocabulary & 2 & 10 \\
\hline 5 & Mechanics & 1 & 5 \\
\hline & Total score & & 100 \\
\hline
\end{tabular}

The effect of the feedback was measured by comparing the scores of the students individually in composing their writing after receiving direct corrective feedback with their scores revising their writing with scaffold indirect corrective feedback from the teacher. The statistical computation was administered by using SPSS 16. The data were analyzed using paired sample ttest. The results of the statistical measurement were analyzed as how effective the types of teacher corrective feedback on students' writing quality. 
Table 2. The activities for data collection

\begin{tabular}{|c|c|c|c|}
\hline Meeting & Group 1 & Group 2 & Writing prompt \\
\hline 1 & $\begin{array}{l}\text { Writing 1: The students were } \\
\text { asked to write the writing } \\
\text { composition } 1 \text { in the classroom, } \\
\text { then they were given direct } \\
\text { correction feedback. }\end{array}$ & $\begin{array}{l}\text { Writing 1: The students were asked to } \\
\text { write the composition } 1 \text { in the } \\
\text { classroom, then they were given } \\
\text { indirect correction feedback. }\end{array}$ & \multirow[t]{2}{*}{$\begin{array}{l}\text { Now, Indonesian Forest is } \\
\text { on fire. Write an essay based } \\
\text { on your argument how to } \\
\text { overcome Indonesian's } \\
\text { forest fires. }\end{array}$} \\
\hline 2 & $\begin{array}{l}\text { Students received their first } \\
\text { composition back with direct } \\
\text { correction feedback then they were } \\
\text { asked to revise it then submitted } \\
\text { the final revision. }\end{array}$ & $\begin{array}{l}\text { Students received their first } \\
\text { composition back with indirect } \\
\text { correction feedback then they were } \\
\text { asked to revise it then submitted the } \\
\text { final revision. }\end{array}$ & \\
\hline 3 & $\begin{array}{l}\text { Writing 2: The students were } \\
\text { asked to write the writing } \\
\text { composition } 2 \text { in the classroom, } \\
\text { then they were given indirect } \\
\text { correction feedback. }\end{array}$ & $\begin{array}{l}\text { writing } 2 \text { : The students were asked to } \\
\text { write the writing composition } 2 \text { in the } \\
\text { classroom, then they were given } \\
\text { direct correction feedback }\end{array}$ & \multirow[t]{2}{*}{$\begin{array}{l}\text { Many artists were appointed } \\
\text { as member of parliament. } \\
\text { Write an essay (at least } 3 \\
\text { paragraphs) to show whether } \\
\text { you agree or disagree. }\end{array}$} \\
\hline 4 & $\begin{array}{l}\text { Students received their second } \\
\text { composition back with indirect } \\
\text { correction feedback then they were } \\
\text { asked to revise it then submitted } \\
\text { the final revision }\end{array}$ & $\begin{array}{l}\text { Students received their second } \\
\text { composition back with direct } \\
\text { correction feedback then they were } \\
\text { asked to revise it then submitted the } \\
\text { final revision }\end{array}$ & \\
\hline
\end{tabular}

\section{RESULTS}

The aim of the study was to find the individual writing quality of the students after getting feedback, direct and indirect feedback. In analyzing the data, the means score of both scores were compared and analyzed. The means score of the students' writings after receiving direct feedback was 74.19 and the mean score of students' writings after receiving indirect feedback was 70.81 . The difference between the mean score can be seen in Table 3. In order to compare the means of different feedback, a paired sample t-test was conducted. The result of the analysis indicates that there is significant difference between direct and indirect corrective feedback on students' writings quality. It can be seen from Table 4 that the significant value (p.value) is 0.00 . It is lower than 0.05 , it indicates the quality of the students' writings is better after receiving direct corrective feedback than indirect feedback. The detail information about the comparison of the mean scores can be seen in Table 3 .

Table 3. Descriptive statistics for means score.

Paired Samples Statistics

\begin{tabular}{|c|c|c|c|c|}
\hline & Mean & $\mathrm{N}$ & $\begin{array}{c}\text { Std. } \\
\text { Deviation }\end{array}$ & $\begin{array}{l}\text { Std. Error } \\
\text { Mean }\end{array}$ \\
\hline directFB & 74.19 & 26 & 6.870 & 1.347 \\
\hline $\begin{array}{ll}1 & \text { indirect } \\
\text { FB }\end{array}$ & 70.81 & 26 & 7.049 & 1.382 \\
\hline
\end{tabular}

In addition, each component that has been analyzed; content, organization, language use, vocabulary, and mechanic has slightly differences. In term of content, both revisions after receiving direct and indirect feedback were understood and relevant to the topic given. The content of students' writing was clear. It can be identified by the flow of the essay can be understood well. This happen can be caused by the comprehension of the students of the topic given. most of the message or the idea of the students' essay can be read and understood by the reader. Their writing was fulfilled by thesis statement, and the idea was developed well. The development of the idea was based on their experience and opinions

In term of organization, the students' writings were good. Based on the analysis of the result of students' writing, the organization of the students' writings were developed by the teacher feedback. Students' logical sequences of ideas were appropriate with the topic. Most of the students improve their organization through receiving direct and indirect feedback from the teacher.

However, in term of language use, especially on the grammatical aspect, the revisions of the writing after receiving indirect feedback were relatively more frequent. Consequently, the effect of grammatical errors was made by students affected the meaning so that the idea of the sentences was not clear. In term of vocabulary and mechanic, both qualities of writing were similar in term of their correctness. 
Table 4. Comparison of scores using paired sample t-test.

Paired Samples Test

\begin{tabular}{|c|c|c|c|c|c|c|c|c|c|}
\hline & & \multicolumn{5}{|c|}{ Paired Differences } & $\mathrm{t}$ & df & Sig. (2-tailed) \\
\hline & & \multirow[t]{2}{*}{ Mean } & \multirow[t]{2}{*}{ Std. Deviation } & \multirow[t]{2}{*}{$\begin{array}{l}\text { Std. Error } \\
\text { Mean }\end{array}$} & \multicolumn{2}{|c|}{$\begin{array}{c}95 \% \text { Confidence Interval } \\
\text { of the Difference }\end{array}$} & & & \\
\hline & & & & & Lower & Upper & & & \\
\hline Pair 1 & $\begin{array}{l}\text { directFB } \\
- \\
\text { indirect } \\
\text { FB }\end{array}$ & 3.385 & 3.774 & .740 & 1.860 & 4.909 & 4.572 & 25 & .000 \\
\hline
\end{tabular}

\section{DISCUSSION}

Based on the result of the inferential statistic, it shows that there is a significant difference between direct corrective feedback and indirect corrective feedback on the students' writings quality. In this case, the result shows that the quality of the students' writings is better after receiving direct corrective feedback than after receiving indirect corrective feedback. This research finding confirms the findings of several studies related to short term effect. Muth'im and Latief [12] argues that a university level student is able to correct their errors on their own and corrective feedback is effective on short term revision. The direct feedback gives good impact on student's revision on short term, and it does not give long term effect in learning. In addition, in short term effect, the students who received direct feedback write more accurately than students who received indirect feedback [14].

Furthermore, the students who received direct feedback tend to have smaller errors in their revisions. Considering the limited time in doing revision, students have to revise their writings in the classroom, direct feedback seems to help the students in revising their writing draft properly. After receiving direct feedback students did not do the same error on grammar. This finding confirms the finding that direct corrective feedback enables students to see their errors and enable them to do self-correction [14], [15], and [10]. In addition, direct feedback is better for the revising purpose than indirect feedback. However, the result of this study is different from the study conducted by [3] . the effect of the use of feedback on the correctness of the grammar as his focus. He claims that score of the students cannot be thought as prediction of the improvement of the correctness of targeted structures.

Students who received direct feedback having smaller errors in grammatical aspect than those who received indirect feedback. There is a different finding between present study and a study was done by Tan and Manochphinyo [16]. They compared the effectiveness of direct and indirect teacher written corrective feedback in EFL learners and their study was focused on the grammatical accuracy.
Tan and Manochphinyo's finding shows that direct corrective feedback did not affect the improvement of students' writing correctness on singular or plural. It means that five features out of the six aspects investigated (tenses, subject-verb agreement, articles, singular/plular, preposition, adjectives/adverbs) increased. Through direct feedback, students were not aware of their mistakes so that they made the same mistake when they composed new essay. There is possible explanation of the different finding between the present studsy and the previous study, the present study focuses on the short term effect in doing revision. The students were asked to write two sets of writings with direct and indirect feedback immediately aftewards and the score of the revision were immediately compared. On the other hand, the previous study looked at the effect of direct and indirect feedback on new pieces of writing a month after the treatment (direct and indirect corrective feedback) given.

The familiarity of the topic should be considered as one of the important point in writing. The topics given by the teacher in this study were current news in Indonesia. The familiarity of the topic may help students easier in arranging their writing. The content, organization, language use, vocabulary, and mechanic of the students' writing better after receiving feedback both direct and indirect feedback. Although the students who receive direct feedback have better achievement in grammatical errors correctness, students who receive indirect feedback asked the teacher when they found difficulties in understanding the feedback. From this phenomenon, can be said that the teacher should provide additional explanation of the feedback. the explanation of the feedback may give additional insight for the students when they do revision after receiving and understanding the feedback given by the tecaher. Indirect feedback with explanation provided by the teacher help students in understanding the feedback so that they can write better than the students' first composition [6]. 


\section{CONCLUSION}

Based on the discussion, the quality of the students' writings after receiving direct feedback is better than those who received indirect feedback. Direct corrective feedback improves students' grammatical awareness in short term effect. The awareness of the students in revising their writing is also one of the plausible explanations of why the quality of the students writing with direct feedback is better than of indirect feedback. While after receiving indirect feedback, some students still make errors in grammatical aspect. Based on the result of the study, English teacher can apply direct corrective feedback in achieving the best result of the students' composition and to raise students' awareness of the errors they have made. In addition, this study focused on the quality of writing with the small size of participants so that it is suggested to conduct the same research with larger size of participants in order to confirm the effectiveness of different types written corrective feedback. Furthermore, a particular aspect of grammatical errors can be investigated further to know the effectiveness of each type of written corrective feedback.

\section{ACKNOWLEDGMENT}

The first author of this study sends special thanks to DRPM Kemenristek Dikti, 2021, Republic Indonesia for providing financial support this research.

\section{REFERENCES}

[1] R. Ellis, "A typology of written corrective feedback types," ELT J., vol. 63, no. 2, pp. 97107, 2009.

[2] C. Tang and Y. T. Liu, "Effects of indirect coded corrective feedback with and without short affective teacher comments on L2 writing performance, learner uptake and motivation," Assess. Writ., vol. 35, no. December 2017, pp. 2640, 2018.

[3] J. A. Boggs, "Effects of teacher-scaffolded and self-scaffolded corrective feedback compared to direct corrective feedback on grammatical accuracy in English L2 writing," J. Second Lang. Writ., vol. 46, no. May, 2019.

[4] S. Benson and R. DeKeyser, "Effects of written corrective feedback and language aptitude on verb tense accuracy," Lang. Teach. Res., vol. 23, no. 6, pp. 702-726, 2018.

[5] C. G. Van Beuningen, N. H. De Jong, and F. Kuiken, "Evidence on the Effectiveness of Comprehensive Error Correction in Second Language Writing," Lang. Learn., vol. 62, no. 1, pp. 1-41, 2012.

[6] J. Bitchener and U. Knoch, "The contribution of written corrective feedback to language development: A ten month investigation," Appl. Linguist., vol. 31, no. 2, pp. 193-214, 2010.

[7] A. R. Septiana, G. H. Sulistyo, and A. E. Kadarisman, "Corrective Feedback and Writing Accuracy of Students Across Different Levels of
Grammatical Sensitivity," ndonesian J. Appl. Linguist., vol. 6, no. 1, pp. 1-11, 2016.

[8] T. Elhawwa, D. Rukmini, J. Mujiyanto, and D. Sutopo, "Effect of Focused and Unfocused Feedback on Learners' Writing Accuracy within Different Gender and Cultural Background Groups," Arab World English J., vol. 10, no. 3, pp. 382-400, 2019.

[9] K. Kurzer, "Dynamic Written Corrective Feedback in Developmental Multilingual Writing Classes,' TESOL Q., vol. 52, no. 1, pp. 5-33, 2017.

[10] Y. Sheen, "The Effect of Focused Written Corrective Feedback and Language Aptitude on ESL Learners 'Acquisition of Articles," TESOL Q., vol. 41, no. 2, pp. 255-283, 2007.

[11] D. Frear and Y. H. Chiu, "The effect of focused and unfocused indirect written corrective feedback on EFL learners' accuracy in new pieces of writing," System, vol. 53, pp. 24-34, 2015.

[12] A. Muth'im and M. A. Latief, "The effectiveness of indirect error correction feedback on the quality of students' writing," Arab World English J., vol. 5, no. 2, pp. 244-257, 2014.

[13] W. Suzuki, H. Nassaji, and K. Sato, "The effects of feedback explicitness and type of target structure on accuracy in revision and new pieces of writing," System, vol. 81, pp. 135-145, 2019.

[14] J. Bitchener, "Evidence in support of written corrective feedback," J. Second Lang. Writ., vol. 17, no. 2, pp. 102-118, 2008

[15] J. Bitchener and U. Knoch, "Raising the linguistic accuracy level of advanced L2 writers with written corrective feedback," J. Second Lang. Writ., vol. 19, no. 4, pp. 207-217, 2010.

[16] K. E. Tan and A. Manochphinyo, "Improving Grammatical Accuracy in Thai Learners' Writing: Comparing Direct and Indirect Written Corrective Feedback," J. Asia TEFL, vol. 14, no. 3, pp. 430 442, 2017. 